\title{
Capital constraints and the performance of entrepreneurial firms in Vietnam
}

Hien Thu Tran*** and Enrico Santarellit*, ${ }^{*}$

Entrepreneurship has been among the key driving forces of the emergence of a dynamic private sector during the recent decades in Vietnam. This article addresses for Vietnam the questions "how capital constraints affect the performance of family firms" and "how entrepreneurs' human and social capital interact with capital constraints to leverage entrepreneurial income." A panel of 1721 firms in 4 years is used. Results are consistent with the resource dependency approach, indicating an adverse effect of capital constraints on firm performance: firms suffering capital constraints perform substantially better, suggesting that they need more capital simply to finance newly recognized profit opportunities. Human capital plays a vital role in relaxing capital constraints and improves the entrepreneurial performance, whereas the effect of social capital stemming from strong ties and weak ties is limited: strong ties bring emotional support and weak ties give nonfinancial benefits from regular and useful business contacts. Advanced econometric analysis tools to take into account the endogeneity of capital constraints are used to establish relationships among relevant variables.

JEL classification: G24, L26, L25, L14.

\section{Introduction}

It is widely accepted that entrepreneurship is a crucial force of economic and social development (Schumpeter, 1934; Audretsch, 1995; Shane and Venkataraman, 2000),

${ }^{\star}$ Hien Thu Tran, Department of Economics, University of Bologna, Piazza Scaravilli, 2 - 40126 Bologna, Italy. e-mail: thuhien.tran@unibo.it

${ }^{\star \star}$ Hien Thu Tran, Centre of Commerce and Management- RMIT International University, Hanoi, Vietnam.

${ }^{\dagger}$ Enrico Santarelli, Department of Economics, University of Bologna, Piazza Scaravilli, 2 - 40126 Bologna, Italy. e-mail: enrico.santarelli@unibo.it

*Enrico Santarelli, RCEA (Rimini Centre for Economic Analysis), Rimini, Italy.

${ }^{\S}$ Main author for correspondence. 
which manifests itself through a process of discovery, evaluation, and exploitation of opportunities for creating future goods and services (Venkataraman, 1997; Shane, 2000). The presence of constraints to the exploitation of such opportunities, which might hinder the entrepreneurial ability to create value across time has created room for a series of policy actions, ranging from those aimed at strengthening the training capacity of business education in colleges and schools, to those aimed at promoting the emergence of local clusters of the industrial district type, to those providing business development services, to those promoting microfinance support programs addressing financial constraints of start-up firms (loan schemes, tax incentives and exemption, etc.). The emergence of these public programs has established a strong assumption that scant availability of human capital, institutional constraints to community building, and limited access to financial capital may significantly erode entrepreneurial performance, which has been the dominant hypothesis in a number of studies on start-up entrepreneurship (Evans and Jovanovic, 1989; Cooper et al., 1994; Bosma et al., 2000; Parker and van Praag, 2006; Dilek et al., 2012). Nevertheless, research seeking to single out the causes of observed performance differentials across entrepreneurial firms has mostly focused on developed or advanced countries, whereas there is little empirical evidence for transition countries.

To bridge this gap, in the present article we follow the approach residing at the crossroad between economics and management sciences that has focused on the factors that breed entrepreneurial success (see, among others, Schiller and Crewson, 2007; Hitt et al., 2011; Lumpkin et al., 2011; Unger et al., 2011).Our focus is on how entrepreneurial firms can achieve and maintain success by benefiting from various sources of competitive advantage. In particular, we investigate the effect of capital constraints on the subsequent performance of family businesses in Vietnam, taking into account the possibility that human capital and social capital, by boosting financial capital and easing access to credit, might also have indirect effects on family firms' ability to create and sustain a competitive advantage. Consistent with the recent literature (La Porta et al., 1999; Astrachan and Shanker, 2003; Poza et al., 2004; Lumpkin et al., 2011), entrepreneurial firms in our sample are typical family firms because they simultaneously display convergence of ownership and control, family involvement in management, and realization of family succession.

Whereas they have been widely studied in relation to developed countries, ${ }^{1}$ little empirical research has been conducted to identify their importance, distinctiveness, and challenges in post-socialist transition economies. ${ }^{2}$ Because Vietnam is characterized by a community culture favoring mutual trust and reciprocity among

\footnotetext{
${ }^{1}$ See, among others, Dyer and Handler, 1994; Perman, 2006; Shim and Okamuro, 2011.

${ }^{2}$ See, among others, Claessens et al. (2002); Luo et al. (2005); Yordanova (2011); Santarelli and Tran (2012).
} 
family/network members, it is obvious that family firms among the population of firms in the private sector take up a critical contribution to both their local and national economy. Approximately, family firms in Vietnam take up around $90 \%$ of all enterprise and around $80 \%$ of employment (GSO, 2007). They normally start at microsize, adopt household ownership, stay in agricultural sector, and locate in rural areas, which results insignificant challenges for their survival and growth that calls for timely development policies and support from the government.

The contribution of this article is both empirical and methodological. First, we study the interaction of human capital, social capital, and financial capital constraints and estimate their combined effects on the entrepreneurial performance of family firms. Second, we assess the causal effects of entrepreneurs' financial capital constraints on their performance, by modeling these constraints as an endogenous variable. For this purpose, we apply instrumental variable (IV) generalized method of moments (GMM) technique to control for endogeneity after adopting Hausman's test confirming the endogeneity of financial capital constraints. This is a novelty with respect to most of previous empirical studies, which have just treated financial capital constraints as exogenous when exploring their impacts on entrepreneurial performance. With this approach we are instead able to give useful and consistent insights as to whether endogeneity is a potential issue.

The article is structured as follows. Section 2 surveys the literature on the issues under investigation, Section 3 describes the data set, Section 4 sets up the empirical strategy, Section 5 presents the empirical results, and the concluding section summarizes the main findings and draws some policy suggestions.

\section{Theoretical background}

As research expands and matures, an increasing range of organizational theories is being applied in the family firm context: agency theory (Faccio et al., 2001; Schulze et al., 2001; Burkart et al., 2003; Chrisman et al., 2004; Dyer, 2006; Stewart and Hitt, 2012), stewardship theory (Miller et al., 2008; Zahra et al., 2008), resource-based view (Chrisman et al., 2005; Dyer, 2006; Westhead and Howarth, 2006), and transaction costs theory (for a review, see Verbeke and Kano, 2012). These theories are adopted to explain unique features of "family effects," i.e. family goals, family resources, and owner-management relationships, and how they are different from those of nonfamily firms in determining the organizational performance. Contradictory findings have emerged from most of the empirical evidences presented to test these theories (Dyer, 2006). Besides, when coming to explore the "family effects" on the likelihood of a family firm being capital constrained there is still a lack of influential theories.

Agency relationships arise when the entrepreneur calls for external investment from venture capitalists, banks, or external investors for setting up his/her new business. As a result of incongruent goals, self-utility maximization, and bounded 
rationality, information asymmetry between entrepreneurs and investors will allow entrepreneurs to engage in opportunistic behaviors at the expense of outside investors (Amit et al., 1990, 1998). Agency theory proposes that on one side, owing to a substantial absence of conflicts of interest between owners and managers, family firms may be characterized by a superior performance as compared with their widely held counterparts (Fama and Jensen, 1983). But on the other side, it submits that self-control problems and conflict of interests among family shareholders will allow inside owners to use their power to extract private benefits for their personal interests at the expense of outside owners/investors.

Traditionally, the logic of agency theory has been extended to explain the relationship between venture capitalist (external investor) and entrepreneur (Amit et al., 1990; Sahlman, 1990; Sapienza and Gupta, 1994) as a source of capital constraints for start-ups in general. To avoid and mitigate the consequences of agency problems as well as safeguard their investment, investors use various monitoring mechanisms and incentives. On one hand, they require business owners to invest a substantial portion of their personal wealth in the new venture, acting as a reliable self-bonding such that it cannot be retrieved and redeployed if the new business fails. On the other hand, legally binding and comprehensive obligations are clearly specified in financing contracts, and direct involvement of investors in monitoring the business will partly reduce the likelihood of moral hazard on the part of the entrepreneur.

An important stream of literature has investigated the impact of financial constraints on the initial performance of new firms, mostly bringing the tradition initiated by Fazzari et al. (1988) in their seminal study on the effect of cash flow on investment into the field of entrepreneurship and small business economics (for a survey cf. Santarelli and Vivarelli, 2007). Inadequacy in financial resources is often a primary reason for the failure of emerging businesses, given that firms with greater financial resources can invest more in product/service development and have a larger financial cushion to handle market downturns or managerial mistakes than firms devoid of financial resources that are subject to credit rationing (Stiglitz and Weiss, 1981). However, the question here is the relationship between access to capital and investment decisions of entrepreneurs. If capital markets are assumed to be perfect, external funds provide a perfect substitute for internal capital, making the initial financial conditions of the entrepreneur irrelevant to his/her investment and, therefore, his/her ability to create and sustain a competitive advantage. But, if capital markets are assumed to be less perfect, say, owing to the existence of imperfect and asymmetric information, then it may become costly and sometimes even impossible for providers of external finance to evaluate the quality and feasibility of an entrepreneur's investment opportunities. As a consequence, internal and external capital sources are not perfectly substitutable. Agency theory traces imperfect credit markets to asymmetric information. Lenders do not have sufficient information about the creditworthiness of borrowers or risks of a project, which they are financing. Good and creditworthy borrowers do not necessarily become 
selected as credit customers; and debt holders may allocate obtained loan to execute more risky projects.

In contrast with agency theory's assumption of managers' self-serving goals, stewardship theory suggests that organizational managers are motivated to serve as loyal stewards of their firms and owners, acting in the organization's best interest to achieve its mission and vision. Stewardship theory has been applied to explore the unique competitive advantage of family firms, stemming from the inherent tendency toward stewardship behaviors of family leaders (see Miller et al., 2008; Zahra et al., 2008). They "exhibit much care about business continuity, community, and connection: specially, about long-term preservation and nurturing of their business and its markets, the fostering of talent and effective deployment of employees, and an emphasis on growing and sustaining relationships with clients" (Miller et al., 2008: 73). The special attachment resulting from kinship relationship, a single family name, and a common history develops and maintains "a shared identity in family firms and contribute to building enduring social capital that can be relied upon through generations" (Verbeke and Kano, 2012: 1189).

Both the resource-based view of the firm and transaction costs theory focus on family firms' competitive advantage stemming from their unique human, financial, and social resources and assets. "Valuable, rare, inimitable, and nonsubstitutable" resources of family firms come from a common "family name" (Dyer, 2006: 262), which inspires natural commitment and loyalty from family members (Ward, 1988) and allows an early "socialization process" to capture hands-on experience from family leaders (Dyer, 1992). The early involvement of family members in the business to prepare themselves for future leadership roles without formal contracting becomes a primary coordination mechanism in the family firm. Consistent with transaction costs theory, this is associated to a type of "asset specificity" stemming from unique human capital base available to family firms (Verbeke and Kano, 2012). On one hand, familybased human asset specificity guarantees a stable and loyal human resource base with limited danger of adverse selection for the firm; on the other hand, "bounded rationality" of family members will place constraints on quality and quantity of financial resources, which reduces the firm's capacity in exploiting and adjusting optimally its resource base swiftly as a function of economic change, and hence resulting in capital constraints (Carney, 2005). Therefore, it is crucial to capture the established relationships between these unique human and social resources of family firms and their vulnerability to capital constraint as well as organizational performance.

Transition economies are characterized by high levels of resource constraints in the form of shortage of managerial and technical skills and expertise, financial resources, and technology. Astrachan (2010) observed that the business environment in transition economies is volatile and fragile and therefore endangers the survival of family firms because of unsophisticated regulatory systems providing financial and other resource support. One way of acquiring resources and capabilities in transition economies by family-owned firms is the utilization of unique human capital assets 
and networking relationships and ties (Miller et al., 2009). Due to the owner management nature of family businesses, they tend to be overly dependent on a single decision maker (Feltham et al., 2005). Thus, it is crucial to investigate how the characteristics of family firm entrepreneur (taking the role as the manager/owner) as well as the overall family involvement in the business influence the entrepreneurial behavior and subsequent organizational performance of new ventures.

Many researchers have attempted to measure the correlation between the entrepreneur's human/social capital and the subsequent entrepreneurial performance (Pennings et al., 1998; Parker and van Praag, 2006; Santarelli and Tran, 2013). However, the interaction among three key variables-entrepreneurs' human/social capital, entrepreneurial behavior with respect to accessing capital, and entrepreneurial performance after start-up-is far beyond our knowledge. In this respect, the resource-based view proves useful in positing that social capital is an important asset for family firms because it allows them to gain access to other forms of capital, e.g. financial capital, human or intellectual capital, that are essential for them to survive and prosper. Families have some unique advantages in developing social capital between the family and firm stakeholders through long-standing personal, rather than impersonal, relationships across generations (Simon and Hitt, 2003). The nature of enduring family connections and commitments brings certain social benefits by reducing transaction costs, solving problems of coordination and easing the access to resources that are not available to other nonfamily firms.

Empirically, while education level is conceived as an entrepreneur's prior knowledge brought to the labor market and significantly determines his/her entrepreneurial performance, another factor, social capital, could boost up his/her entrepreneurial success through its complementary effect from its interaction with human capital (Santarelli and Tran, 2013). The collective view of social capital considers it as social networks provided by extended family- or community-based relationships (Putnam, 1993). The collective view argues that these social networks are likely to amplify the effects of education, experience, and financial capital by facilitating resource transfer and social support in the entrepreneurial process (Lin, 1990). Significant empirical research shares the consensus that entrepreneurs' social networks supplement the effects of human and financial capital (Aldrich and Zimmer, 1986; Johannisson, 1988). Network members use their personal network of private and business contacts to acquire resources and information that they would not (or not as cheaply) be able to acquire on markets. Benefits from social networks can range from access to a variety of scarce (Zimmer and Aldrich, 1987) and intangible resources (Bruderl and Preisendorfer, 1998), to necessary information and advices on daily business decisions (Smeltzer et al., 1991; Brown and Butler, 1995). By emphasizing prior interaction and cultural similarity among individuals, participation in networks that enable an individual to overcome imperfect information problems and form contracts with others (Glaeser et al., 2000) may well act as a factor of a financially constrained individual being successfully involved in entrepreneurial activities. In 
the microfinance literature, it seems to be taken for granted that social capital, social relations, networks, and so forth ease up credit constraints in the forms of joint liability credit groups or as a screening device for rationing heterogeneous borrowers (Dinh et al., 2012; Dufhues et al., 2012).

\section{Overview of the Vietnamese case and data description}

After Vietnam abandoned central planning in 1986, many private enterprises have been established, with only a few of them set up through the transfer from state to private ownership. Consequently, the 32-year-long experience of central planning in Vietnam ended-up with the emergence of a young entrepreneurial class devoid of business experience in either domestic or international markets (Abrami, 2003; Tran-Nam and Pham, 2003; Hiemstra et al., 2006; Gutterman, 2011). Modern Vietnam inherited from the communist one-party political system many institutional constraints, with complex administrative regulation, excessive bureaucracy, and frequent changes in requirements increasing the risk and cost of doing business for private entrepreneurs. Besides, "red tape" requirements still permeate all levels of the hierarchy, the system is dispersed and disorderly, corruption and bribery are common, public servants are unskilled and under-qualified, economic growth is accompanied by increased inequality (Glewwe and Dang, 2011; De Jong et al. 2012; Rand and Tarp, 2012). As a consequence, although the government has recognized entrepreneurial activities as an essential driver of economic growth, entrepreneurship so far has not brought about the desired effects.

Along with a long-standing negative perception of doing business in Vietnamese culture (Hoang and Dung, 2009), among the reasons of the slow development of a strong entrepreneurial orientation in Vietnam there is the lack, common to most post-socialist transitional economies of an established system of entrepreneurial finance. Since the early 1990s, shortage of capital was at the top of the list of constraints identified by Vietnamese entrepreneurs in almost every survey on private small firms in the country. However, Rand (2007) in attempting to determine the cost of capital in Vietnamese manufacturing indicates that the role of formal loans is relatively unimportant for new business founders in comparison with that of informal loans as well as personal savings. Collateral requirements represented the largest obstacle to access loans of significant size and maturity from the formal financial system. Thus, entrepreneurs were used to rely on personal savings and informal credit markets, even in the form of interest-free loans or gifts from family members or friends, ${ }^{3}$ for start-up capital and to finance the first months of operations. Nevertheless, the situation has improved recently with regard to access to formal

\footnotetext{
${ }^{3}$ Whereas interest-free loans from relatives and friends take the form of equity financing, and are therefore a type of external financing, gifts from relatives and friends can be considered as de facto
} 
capital as a result of changes in credit regulations that eased the access to bank loans for the private sector. In particular, when the new Law on State Bank and the Law on Financial Institutions came into force, in 1998 the entire financial system was strengthened and readdressed toward a more market-oriented approach. This reform process led to a rapid increase of total credit granted by the largest stateowned commercial banks to the domestic private sector in the following decades (World Bank, 1999, 2005; Phuong, 2003). Nevertheless, until recently the stateowned commercial banks' reliance on political connections in determining loan access has not served to direct credit to more profitable enterprises (Malesky and Taussig, 2009).

In general, Vietnamese culture embeds strong family and community values in every business activity and the whole macro business environment. Family firms play a vital role in the economy of Vietnam, yet they are poorly understood and there is little work on how family-owned firms use their human capital and social networks to obtain resources and leverage them from initial capital constraints to create competitive advantage. On one hand, it is likely that Vietnamese family firms get similar impacts from external business environment and share some common features and determinants for success with nonfamily peers. On the other hand, the nature of family ownership will give them some unique characteristics both enhancing and impeding their performance, such as family contractual relationships, the influence of altruism on agency relationships, inheritance and continuity, avoidance or reduction of business risk, and so forth. Recent work argues that rural Vietnamese, taking up $70 \%$ of the population, suffer significant credit constraints due to poorly functioning credit markets (Barslund and Tarp, 2008).

The data set used in our empirical investigation is a 4-year panel of Vietnamese private manufacturing enterprises from 2003 to 2006. The data set is extracted from the two Danish International Development Agency (DANIDA) surveys carried out in 2005 and 2007 covering rich information on various aspects of entrepreneurs and their firms under the collaboration between Ministry of Labor, Invalids and Social Affairs in Vietnam, and the Department of Economics, University of Copenhagen, Denmark. In which the 2005 survey has financial information of 2003 and 2004, and the 2007 survey has financial information of 2005 and 2006. The surveys are broadly representative of the Vietnamese population of entrepreneurs. The sample was drawn randomly from a complete list of enterprises, where the stratified sampling procedure was used to ensure the inclusion of an adequate number of enterprises in each province with different ownership forms (for a comprehensive understanding of the surveys, see Rand and Tarp, 2007). Entrepreneurs are considered as business owners who started their own ventures or took over an existing business.

internal financing. Entrepreneurs with a preference for higher independence will be more reluctant to accept any kind of equity financing. 
Table 1 Tabulation of legal ownership types and size of firms (2006)

\begin{tabular}{lclcllr}
\hline Firm size & $\begin{array}{l}\text { Household } \\
\text { enterprises }\end{array}$ & Private & $\begin{array}{l}\text { Partnership/ } \\
\text { cooperative }\end{array}$ & $\begin{array}{l}\text { Limited } \\
\text { liability }\end{array}$ & $\begin{array}{l}\text { Joint } \\
\text { stock }\end{array}$ & Total \\
\hline Microsize & $1232(94.84)$ & $33(2.54)$ & $9(0.69)$ & $23(1.77)$ & $2(0.15)$ & $1299(100)$ \\
Small size & $201(54.91)$ & $57(15.57)$ & $12(3.28)$ & $88(24.04)$ & $8(2.18)$ & $366(100)$ \\
Medium size & $5(8.93)$ & $7(12.5)$ & $2(3.57)$ & $38(67.86)$ & $4(7.14)$ & $56(100)$ \\
\hline Total & $1438(83.56)$ & $97(5.64)$ & $23(1.34)$ & $149(8.66)$ & $14(0.81)$ & $1721(100)$ \\
\hline
\end{tabular}

Group percentages in parentheses. Micro: 1-9 employees; Small: 10-49 employees; Medium: 50-299 employees (World Bank definition).

We identify family firms in the database as those (i) having "household" ownership type, or (ii) having at least two family members working in the firm, one of whom is the owner of the business if they are limited liability, joint stock, partnership, or private firms. State-owned, state-invested, and foreign-invested firms are excluded from the analysis. For the purpose of the estimation in which we want to investigate the effect of initial capital constraints in the inception year as well as during years in operation on the subsequent entrepreneurial performance of family firms, we include in the sample only those firms having data at the inception year and still surviving until 2006. In other words, failing firms before 2006 are removed from the analysis. The final sample contains 1721 family firms in each year, which forms a balanced panel of $1721 \times 4$ years $=6884$ observations.

The data set contains a wide range of demographic, economic, financial, and social variables, including ones relating to human capital, financial capital, social capital of firms and their business performance. Firms are located in three large metropolitan areas of Hanoi, Haiphong, and Hochiminh City and seven rural provinces (Ha Tay, Phu Tho, Nghe An, Quang Nam, Khanh Hoa, Lam Dong and Long An). Table 1 documents the number of family enterprises sampled in each ownership form category in 2006.

Household business is the dominant ownership type among family firms, accounting for more than $80 \%$ of the total. Of this fraction of family firms, $94 \%$ is represented by microsized firms having fewer than nine employees. Microsized firms occupy $75 \%$ of the sample size, which is somewhat under-representative compared with the 99\% of microsized firms in the whole population (Rand and Tarp, 2007). Table 2 presents the sector-size tabulation (within manufacturing industry). Most family firms reside in basic labor-intensive manufacturing sectors, food processing, textile, footwear $(40 \%)$, and wood/ metal products $(44 \%)$, which are generally technologically backward. 
Table 2 Number of enterprises by size and sector-2005 (1-digit ISIC code level-Only manufacturing)

\begin{tabular}{|c|c|c|c|c|c|}
\hline Industry & Microsized & $\begin{array}{l}\text { Small } \\
\text { sized }\end{array}$ & $\begin{array}{l}\text { Medium } \\
\text { sized }\end{array}$ & Total & Percent \\
\hline Food, textile, and footwear & $549(81.62)$ & $109(16)$ & $23(3.38)$ & $681(100)$ & 39.57 \\
\hline Wood, chemicals, and metal products & $526(69.12)$ & $209(27.46)$ & $26(3.42)$ & $761(100)$ & 44.22 \\
\hline $\begin{array}{l}\text { Electricity, automobile vehicles, } \\
\text { construction }\end{array}$ & $195(69.89)$ & $77(27.6)$ & $7(2.51)$ & $279(100)$ & 16.21 \\
\hline Total & 1270 & 395 & 56 & 1721 & 100.00 \\
\hline
\end{tabular}

Group percentages in parentheses. Micro: 1-9 employees; Small: 10-49 employees; Medium: 50-299 employees (World Bank definition).

Table 3 Number of enterprises by gender and size (2006)

\begin{tabular}{llllr}
\hline Gender & Microsized & Small sized & Medium sized & \multicolumn{1}{l}{ Total } \\
\hline Male & $905(69.67)$ & $260(71.04)$ & $37(66.07)$ & $1202(100)$ \\
Female & $394(30.33)$ & $106(28.96)$ & $19(33.93)$ & $519(100)$ \\
\hline Total & $1299(75.48)$ & $366(21.27)$ & $56(3.25)$ & $1721(100)$ \\
\hline
\end{tabular}

Percentages are in parentheses. Micro: 1-9 employees; Small: 10-49 employees; Medium: 50-299 employees (World Bank definition).

Table 3 presents the gender-size tabulation. Male entrepreneurs account for three quarters of the total sample. They also take somewhat similar share in the total in each size category, a little bit higher for the category of small-sized firms with between 10 and 49 employees.

\section{Econometric strategy}

In this section, an empirical model that simultaneously estimates the effects of financial, human, and social capital constraints on entrepreneurial performance is developed. 


\subsection{Definition of variables}

Entrepreneurial performance is measured by the success of family firms. Because the most widely used measures for entrepreneurial performance are accounting and growth measures (Timmons, 1994), ${ }^{4}$ in this article we use total gross annual business income. Business income is defined as total gross profit from the business before deducting tax and interests but after subtracting business-related costs. We take the logarithm of profit to obtain a reliable measure of the elasticity between firm performance and independent variables. The measure of gross business income could make the estimation biased and meaningless without scaling to size. Thus, we control for the size of family firms with respect to both labor size (number of employees) and economic size (log of total assets). On the other hand, Schulze et al. (2001) propose that growth rate is a more reliable measure of family-firm performance than incomebased measures because privately held firms have incentive to minimize reported taxable income and no incentive to minimize reported sales. Thus, growth of sales is also adopted as another dependent variable. Because taking logarithm of profit will filter out bad performers (making a loss), growth of sales does take into account negative growth in the estimation, and hence helps us understand the overall effect of interested factors on family firms' business performance. Nevertheless, only 18 firms in the sample record their business income as "loss" in a particular year. We separate out the impact of inflation on the real financial performance (sales and profit) of firms in a particular year by deflating current/nominal financial data using the national gross domestic per capita (GDP) deflator for private sector (Table 4).

Human capital enters our model in its three components: (i) education, proxied with entrepreneurs' prior knowledge, enters the analysis as a dummy variable, differentiating the high-educated business founders (university/college and technical high school) from the less-educated ones (vocational training or no education); (ii) industry experience; and (iii) self-employment experience, which are also measured as dummies attaining value one if the entrepreneur possesses that experience, and zero otherwise.

There are as many ways to measure social capital as there are definitions. In contrast to human capital, which is based in individuals, social capital resides in relationships (Coleman, 1988). Social capital is conceived as benefits obtained from entrepreneurs' personal and formal business networks/associations. We adopt the Granovetter's (1973) model, in which network partners are classified in terms of "strong ties" and "weak ties". Strong/weak social ties are relations with high/low levels of emotional attachment, including the entrepreneur's family, relatives, and friends. Bruderl and Preisendorfer (1998), Davidsson and Honig (2003), Greve and Salaff (2003) claim that support from strong ties is more important than support

\footnotetext{
${ }^{4}$ For a review on the classification of performance measures of entrepreneurial ventures, see Deeds et al. (1998).
} 
Table 4 GDP Deflator (2000-2008)

\begin{tabular}{|c|c|c|c|c|c|c|c|c|c|}
\hline \multirow[t]{2}{*}{ Categories } & \multicolumn{9}{|c|}{ Unit: \% } \\
\hline & 2000 & 2001 & 2002 & 2003 & 2004 & 2005 & 2006 & 2007 & 2008 \\
\hline Total & 1.6 & 1.6 & 1.7 & 1.8 & 2.0 & 2.1 & 2.3 & 2.5 & 3.0 \\
\hline \multicolumn{10}{|l|}{ By type of ownership } \\
\hline State & 1.5 & 1.5 & 1.6 & 1.7 & 1.9 & 2.0 & 2.1 & 2.3 & 2.7 \\
\hline Nonstate & 1.6 & 1.6 & 1.7 & 1.8 & 1.9 & 2.1 & 2.2 & 2.4 & 2.9 \\
\hline Collective & 1.6 & 1.6 & 1.7 & 1.8 & 1.9 & 2.0 & 2.2 & 2.4 & 2.9 \\
\hline Private & 1.5 & 1.6 & 1.6 & 1.7 & 1.8 & 2.0 & 2.1 & 2.3 & 2.8 \\
\hline Household & 1.6 & 1.6 & 1.7 & 1.8 & 1.9 & 2.1 & 2.3 & 2.4 & 3.0 \\
\hline Foreign investment sector & 2.0 & 2.1 & 2.2 & 2.4 & 2.6 & 2.8 & 3.0 & 3.3 & 4.2 \\
\hline \multicolumn{10}{|l|}{ By kind of economic activity } \\
\hline Agriculture, forestry, and fishery & 1.7 & 1.7 & 1.8 & 2.0 & 2.1 & 2.3 & 2.5 & 2.8 & 3.8 \\
\hline Industry and construction & 1.7 & 1.7 & 1.8 & 1.9 & 2.0 & 2.2 & 2.3 & 2.5 & 2.9 \\
\hline Service & 1.5 & 1.6 & 1.6 & 1.7 & 1.9 & 2.0 & 2.2 & 2.3 & 2.8 \\
\hline
\end{tabular}

Source: GSO, 2010.

from weak ties in all phases of establishing a firm. The presence of an entrepreneur in the family can compensate for financial and managerial restrictions. Further, emotional support received from a family member who is an entrepreneur might be helpful to sustain emotional stability. We include two variables to get an impression about the role of family members, relatives, and friends in both the start-up and growth period of family businesses: (i) financial support, captured by the percentage of initial investment capital as loans from strong ties; (ii) emotional support, as a dummy to indicate the likelihood of receiving emotional support and encouragement from other family entrepreneurs. Weak ties are based on relations devoid of any emotional attachment, such as those with acquaintances, business partners, and colleagues. Granovetter (1973), Putnam (1993), Davidsson and Honig (2003) emphasize the "strength of weak ties" and argue that weak ties are less reliable but provide access to a variety of new information and knowledge during the recognition and exploitation period of entrepreneurial opportunities. We will examine the "network success hypothesis" to understand the effect of entrepreneurs' formal business network participation on subsequent business performance. Three variables will be constructed: (i) formal business network participation, which is a dummy attaining value one if the entrepreneur joins one or more than one network, ${ }^{5}$ and zero

\footnotetext{
${ }^{5}$ The dummy combines the answers to two questions: "Do you participate in one business network?" and "Do you participate in more than one network?".
} 
otherwise; (ii) network size, ${ }^{6}$ which is the sum of regular contacts (at least once every 3 months) that entrepreneurs find useful for their business operations in four categories (business people in the same line of business and in different lines of business, bank officials, and mass organizations); and (iii) network intensity, i.e. frequency of network assistance in a year. ${ }^{7}$

Capital constraints (often referred as credit constraints) have been generally measured in two ways. The indirect method indicates the presence of credit constrains from violation of the assumptions of the permanent income hypothesis. The common proposition is that "without the presence of credit constraints, transitory income shocks should not affect consumption." Prominent literature applying this method includes Deaton (1990), Browning and Lusardi (1996). However, evidences from this permanent income approach are inconclusive because a number of other intrinsic and extrinsic factors influencing human consumption level under conditions of uncertainty, such as precautionary behaviors and initial asset position of firms violate the implication of the permanent income model. The second method of detecting the presence of capital constraints uses direct answers from firms to several qualitative questions on whether they perceive themselves as credit constrained from their participation and experience in the credit market. Typical questions are normally concerned with entrepreneurs' lack of capital, application for loans, experience of rejections from credit holders, or failure to receive sufficient loans. Owing to its straightforward nature, this method has been widely used by various researchers exploiting contextualized surveys in different countries (Feder et al., 1990; Jappelli, 1990; Bosma et al., 2004). Rand (2007) applies this method with direct information from the same survey that this article uses to show that borrowing constraints restrict firm access to credit, and credit-constrained firms would increase their debt by $34 \%$ if borrowing constraints were relaxed. This article will also adopt this method to detect the presence of capital constrains of family firms. Similar to Rand (2007), we categorize firms as being credit constrained based on direct replies to whether the firm applied for credit and if they were denied access in case they applied. However, we also take into account the fact that firms are in need for loans but are not eligible for loans or firms cannot obtain sufficient loans as they desire. Specially, the variable is an interaction dummy formed by responses to the five questions in the DANIDA survey: (i) which difficulties were encountered when the enterprise was established?, and the respondent chose "lack of capital" as the difficulty; (ii) did you apply for loans given the difficulty of lack of capital?; (iii) why you did not apply for loans?; (iv) Did you experience any problems getting the loan?, i.e. being rejected; and (v) Do you still think that you are in need of a loan?. The firm is

\footnotetext{
${ }^{6}$ We define network size as the number of people that the business owners know and interact with personally (Greve and Salaff, 2003).

${ }^{7}$ The variable is operationalized by the answer of the question "how many times a year the entrepreneur receives the assistance in issues directly related to the operation of his firm?".
} 
capital constrained if the interaction dummy attains value 1 in the following three cases, and 0 otherwise:

\begin{tabular}{ll}
$\begin{array}{l}\text { Yes, I encountered lack of capital, applied for loan but faced difficulty in obtaining loan } \\
\text { (being rejected) }\end{array}$ & $5.4 \%$ \\
$\begin{array}{l}\text { Yes, I encountered lack of capital, applied for loan, but still in need for further loans } \\
\text { (could not obtain sufficient loan) }\end{array}$ & $14.3 \%$ \\
Yes, I encountered lack of capital, but did not apply for loan due to & \\
$-\quad$ No collateral mortgage & $3.9 \%$ \\
- Already heavily indebted & $0.17 \%$ \\
- Interest rates too high or the procedure too complicated & $2.24 \%$ \\
\hline Total & $\mathbf{2 6 . 0 1 \%}$ \\
\hline
\end{tabular}

We consider the $26.01 \%$ of entrepreneurs who resided in these three cases as being capital constrained. The other $74 \%$ who did not report "lack of capital" as the difficulty in setting up the business are characterized as facing no capital constraints. Our variable takes into account the possibility of obtaining external capital and the fact that entrepreneurs use their own personal equity to fund their start-ups, either in part of whole. In fact, personal capital is widespread in the DANIDA sample: $60 \%$ of respondents reported that $100 \%$ of investment capital comes from their personal savings; $20 \%$ injected at least $70 \%$ of the total investment as their own savings. It also considers the fact that the entrepreneurs do not apply for loans does not mean that they are not capital constrained. They have low credit scoring (unable to meet criteria for credit granting), lack relevant mortgage, or the apply-for-loan procedure is too complex and time-consuming.

However, several reasons may lead to biased measurement of capital constraints. First, self-reported subjective answers to this question from respondents could result in misleading estimation due to over- or under-reporting. The more, the better: entrepreneurs normally are never satisfied with their available investment budget, and they tend to report capital constraint (or lack of capital) to bargain for other business support (tax exemption). Second, this direct approach is still incapable of providing a satisfactory quantification of the extent to which firms are capital constrained and how capital constraints impact on the subsequent entrepreneurial performance. In other words, as a dummy attaining value one if the entrepreneur reports a constraint and zero otherwise, the variable only accounts for the actual presence and absence of constraints, but fails to indicate different degrees or intensity of capital constraints that a continuous variable can do. The next issue is the possibility that capital constraint is endogenous. It is expected that unobserved individual characteristics, such as ability and motivation, that affect banks' loan scoring and screening procedures may result in different levels of capital constraints and subsequent performance. 
Why some firms are more capital constrained than others? Is it partially due to different levels of entrepreneurial performance pursued by different firms, which are inherently and profoundly influenced by personal characteristics of the firm leader (Kellermans et al., 2008)? Thus, the leader's personal and household characteristics that are likely to affect the extent of capital constraints and entrepreneurial behaviors of family firms such as age, tenure, gender are included as control variables. The entrepreneur's age and tenure may be particularly significant influences on entrepreneurial performance because he/she tends to remain in managerial power much longer than his/her peers in nonfamily firms (Gersick et al., 1997), and thus has an enduring impact on the firm's organizational culture and orientation. The involvement of other family members in managerial positions, especially a trusted successor willing to take over the leadership of the firm, is crucial to guarantee a smooth succession process (Sharma et al., 2003). Hence, number of household members currently working in the enterprise will be controlled in the analysis.

Income and capital constraints might also be affected by entrepreneurs' initial financial circumstances. For example, an entrepreneur who continues to receive some incomes from other income-generating jobs, or who has rich personal savings and support from other family entrepreneurs sufficiently covering total investment required can be expected to relax his/her capital constraint. However, their effects on performance may go either way. The extent of capital constraints might be negatively related to personal equity, but positively related to total capital required. These factors also influence how banks screen various projects: for example, they frequently value strong commitment from those entrepreneurs who inject their own personal equity into the venture. We also control for the likelihood that firms officially register their establishment under the Enterprise Law to obtain the "business registration license." We assume that the formality, under bank screening system, will pave the way to various credit sources. Finally, the size of capital required is contingent on the capital-intensive nature of products and services produced by firms. Thus, we also control for the capital intensity of the industry in which the entrepreneur starts his/her venture, with the expectation that start-ups in capital intensive industries have a greater likelihood of being capital constrained. ${ }^{8}$ Other control variables that potentially affect entrepreneurial performance are current age and size of the firm. Size of the firm is measured in both employment size (logarithm of total number of employees) and economic size (logarithm of total assets of the firm). We control for the survey to take into account any divergence or mismatch arising from conducting two surveys at different time, rather than on yearly basis. Table 5 presents the descriptive statistics of all adopted variables.

\footnotetext{
${ }^{8}$ According to the trade-off theory, because the asset type and risk vary by industries, the average capital structure should also vary by industries (Myers, 1984); thus, firms within the same industries are more alike with respect to their capital structure determinants than firms in other industries (Hall et al., 2000).
} 
Table 5 Summary statistics of financial capital independent variables

\begin{tabular}{|c|c|c|c|c|c|}
\hline Variable & Observations & Mean & SD & Minimum & Maximum \\
\hline \multicolumn{6}{|l|}{ Dependent variable } \\
\hline Annual log income (y) & 6866 & 10.495 & 1.292 & 3.707 & 16.005 \\
\hline Growth of sales & 5158 & 0.329 & 1.506 & -0.949 & 24.567 \\
\hline \multicolumn{6}{|l|}{ Endogenous variable } \\
\hline Capital constraint & 6884 & 0.258 & 0.437 & 0 & 1 \\
\hline \multicolumn{6}{|l|}{ Exogenous variables } \\
\hline $\begin{array}{l}\text { Number of household members } \\
\text { working in the enterprise }\end{array}$ & 6884 & 2.208 & 1.143 & 0 & 14 \\
\hline Current age & 6884 & 46.2 & 9.962 & 20 & 91 \\
\hline Female & 6884 & 0.301 & 0.459 & 0 & 1 \\
\hline Tenure & 6884 & 12.227 & 7.037 & 0 & 58 \\
\hline \multicolumn{6}{|l|}{ Initial human capital } \\
\hline Professional education & 6884 & 0.232 & 0.422 & 0 & 1 \\
\hline Industry experience & 6884 & 0.526 & 0.499 & 0 & 1 \\
\hline Self-employment experience & 6884 & 0.272 & 0.445 & 0 & 1 \\
\hline \multicolumn{6}{|l|}{ Initial financial capital } \\
\hline $\begin{array}{l}\text { Number of other income generating } \\
\text { jobs }\end{array}$ & 6884 & 1.314 & 0.541 & 0 & 7 \\
\hline The firm is the main income source & 6884 & 0.903 & 0.295 & 0 & 1 \\
\hline Initial capital investment & 6884 & 10.878 & 1.939 & 4.605 & 17.239 \\
\hline Personal equity & 6884 & 83.276 & 26.245 & 0 & 100 \\
\hline Debt ratio (total debt/total asset) & 6884 & 0.0888 & 0.3555 & 0 & 13.261 \\
\hline \multicolumn{6}{|l|}{ Initial social capital } \\
\hline Business network participation & 6884 & 0.0674 & 0.251 & 0 & 1 \\
\hline Network size & 6884 & 27.686 & 30.309 & 1 & 506 \\
\hline Network intensity & 6884 & 6.854 & 12.741 & 0 & 70 \\
\hline $\begin{array}{l}\text { Emotional support from self-employed } \\
\text { household members }\end{array}$ & 6884 & 0.151 & 0.358 & 0 & 1 \\
\hline $\begin{array}{l}\text { Loans from family/relatives/friends } \\
\text { (strong ties) }\end{array}$ & 6884 & 9.531 & 19.863 & 0 & 100 \\
\hline \multicolumn{6}{|l|}{ Additional control variables } \\
\hline Capital intensity & 6884 & 0.911 & 1.405 & 0.0053 & 35.92 \\
\hline Registered under enterprise law & 6884 & 0.211 & 0.408 & 0 & 1 \\
\hline Firm labor size & 6884 & 1.701 & 0.995 & 0 & 6.109 \\
\hline Firm economic size (log of total asset) & 6884 & 12.888 & 1.718 & 6.907 & 18.967 \\
\hline Firm age & 6884 & 13.494 & 8.909 & 2 & 78 \\
\hline
\end{tabular}




\subsection{Estimation methodology}

Before figuring out an appropriate estimation model, it is important to be aware of data limitations of the data set. On one hand, many of our independent variables rarely change or do not change at all overtime, such as entrepreneurs' characteristics like age, gender, education, prior experience. Even our key financial explanatory variables, such as capital constraint dummy, initial capital investment, and personal equity, by construction are already determined from the establishment year. On the other hand, due to the surveys' implementation procedure, some nonfinancial variables used are only available/observable for 2004 and 2006, such as social capital variables. Although it is plausible to assume that social factors of firms do not vary much on a yearly basis, our interest is in the initial financial investment/constraint, initial human capital and social capital (that are clearly predetermined and exogenous) on subsequent entrepreneurial performance, not in the variations in firms regarding these variables from year-to-year. Therefore, these time-invariant and rarely changing variables having little explanatory power will result in imprecise coefficient estimates that have large standard errors, and should call for our caution in applying an estimation model for our panel data analysis.

In the context of data sets, the use of fixed effects does more harm than good because it removes all time-invariant effects from the analysis. Plumper and Troeger (2007) propose the fixed-effects vector decomposition estimation (xtfevd procedure), an emerging and popular technique for estimating time-invariant variables in panel data models with group effects. However, critics have been raised against this technique. The decomposition estimator will have higher risk than existing random effect approach, especially if the endogeneity problem of any time-invariant variables is detected (which is the case here, tested below) (Breusch et al., 2011). Therefore, one of the estimation models we apply is random effects.

The existing empirical evidences on capital constraints of firms commonly use the direct method in a straightforward way, in which capital constraint is treated as exogenous, i.e. systematically unaffected by changes in other variables of the model. This assumption is easily violated because it is possible that factors determining the likelihood that a firm is capital constrained (such as income sources, initial investment size, household characteristics of the entrepreneur, or capital-intensity of the industry/sector that the firm operates in) also have influence on its business performance. Thus, in this article, capital constraint is tested and controlled for its endogeneity.

In the following section, we demonstrate the importance of treating capital constraints as endogenous. Under the presence of endogeneity, we apply the IV GMM method, which has been proved to be superior to the conventional two-stage least square if heteroskedasticity is detected (Baum and Schaffer, 2003).The parameters of 
the performance equation accounting for the potentially endogenous capital constraint are estimated by the following two steps:

First step: Random probit estimation. The capital-output ratio (the ratio of total assets to total revenue) is a widely used measure of capital intensiveness among industries (Acs and Audretsch, 1987). For the case of Vietnam, we subtract the value of land from total assets, as land takes the majority part in the total assets of some traditional industries but land evaluation is somewhat biased and problematic in Vietnam. ${ }^{9}$ We use this ratio as an identifying instrument $\mathrm{z}$ (from the above estimation model) for capital constraint. Predicted fitted values will be obtained from this random probit regression.

Second step: robust GMMs estimator (Baum and Schaffer, 2003). The predicted fitted values from the first step will be used as the instrument for the endogenous capital constraint in this regression. Ordinary least squares (OLS) is actually a special case of GMM when heteroskedasticity is not present. However, if heteroskedasticity is present, as it is the case here, ${ }^{10}$ the GMM estimator is more efficient than the OLS estimator (Baum and Schaffer, 2003).

\section{Estimation results}

\subsection{Importance of endogeneity issues}

Capital constraints are likely to be an endogenous variable in the entrepreneurial performance equation (Santarelli and Piergiovanni, 1995). We can test directly the relevance of correcting for endogeneity by applying Hausman's test for endogeneity (1978). The validity of Hausman's test depends on the underlying choice of identifying instruments satisfying quality and validity criteria. The test begins with the reduced form regression and then residuals predicted from this regression are added into the structural form regression. The endogeneity problem is determined based on the significance of the residual coefficient. However, it is impossible to predict residuals as usual with random probit estimation used in the reduced form regression. For binary outcomes, "deviance residual" is in common use. We acquire "probit deviance residuals" through the generalized linear model transformation. ${ }^{11}$

\footnotetext{
${ }^{9}$ Land evaluation system is complex and problematic in Vietnam. Because the people own, and the state manages land, in legal theory it has not market value. Instead, the state has enacted statutory pricing formula for calculating land values. Households have low incentives to claim for land use right to avoid tax. Untitled land transactions incur no transfer tax (while titled land transfers are taxed at 4 percent of the sale price). (AusAid working paper 4, 2000).

${ }^{10}$ The Breusch-Pagan test for heteroskedasticity produces the chi2 statistic of 152.3 with $P$-value of 0.00 , which does not support the hypothesis of constant variance.

${ }^{11}$ McCullagh and Nelder (1989) claim that generalized linear models provide a unified framework, which can be applied to various 'linear' models. Such transformations are referred to as link
} 
Relevance (Hausman's test)

Quality test (correlated with regressors)

Validity test (exogeneity condition) - Hansen J test

$$
\begin{aligned}
\chi 2(1) & =40.65 \\
P & =0.000 \\
\chi^{2}(1) & =9.45 \\
P & =0.0021 \\
\chi^{2}(1) & =2.087 \\
P & =0.148
\end{aligned}
$$

The significance of the statistics given by the relevance test suggests that capital constraints are indeed endogenous in the entrepreneurial performance equation. IV is known to be an appropriate estimator in the presence of endogeneity (Wooldridge, 2000). Following Parker and van Praag (2006), we propose to use industry capital intensity ratio as the IV for capital constraint. We argue that the feature of capital intensity in an industry is related to the likelihood of capital constraints of a firm in that industry, but less likely to determine its performance. Indeed, the IV also passes the quality test and the validity test. The Sargan validity test can be used in overidentifying cases, i.e. when there are more IVs than endogenous ones. Thus, the test is not valid in this case: the model is just identified.

\subsection{First step: Determinants of entrepreneurs' capital constraints}

Table 6 presents estimates of the capital constraint equation by random probit regression.

The key result is that entrepreneurs who have other income-generating sources are significantly more capital constrained. Capital constrained entrepreneurs facing difficulties in obtaining external capital are more motivated to search for other jobs to leverage their income or partly relax capital shortage of their venture. As expected, entrepreneurs located in capital intensive industries are significantly more likely to face capital constraints than those located in industries in which less capital is needed. This effect is complementary to the scale effect from capital required, which is consistent with the perception that banks' screening systems place more reluctance to capital intensive industries with high sunk costs and complicated production techniques. Furthermore, the amount of personal equity injected at the start has a strongly negative effect on the extent of capital constraints. The probability of this effect decreases as the amount of personal business capital increases.

functions. Different types of response variables use different link functions: both the logit and probit link functions work with binomial response variables. The generalized linear models take the form:

$$
\mathrm{g}(\mathrm{E}(\mathrm{y}))=\mathbf{x} \beta, \mathrm{y} \rightarrow\{\mathrm{F}\}
$$

where $\mathrm{F}$ is the distribution family and $\mathrm{g}()$ is the link function. 
Table 6 Estimates of the capital constraint equation

\begin{tabular}{|c|c|c|c|}
\hline Variable & Coefficient & Standard error & $z$-ratio \\
\hline \multicolumn{4}{|l|}{ Initial human capital } \\
\hline Professional education & $-0.246^{\mathrm{a}}$ & 0.122 & -2.02 \\
\hline Industry experience & $0.614^{\mathrm{b}}$ & 0.161 & 3.82 \\
\hline Self-employment experience & $-0.319^{b}$ & 0.099 & -3.23 \\
\hline \multicolumn{4}{|l|}{ Initial financial capital } \\
\hline Number of other income generating jobs & $0.129^{a}$ & 0.082 & 1.8 \\
\hline The firm is the main income source & $0.392^{b}$ & 0.149 & 2.63 \\
\hline Initial capital investment & $0.102^{a}$ & 0.0478 & 2.14 \\
\hline Personal equity & $-0.039^{b}$ & 0.0053 & -7.38 \\
\hline \multicolumn{4}{|l|}{ Initial social capital } \\
\hline Business network participation & $0.728^{\mathrm{b}}$ & 0.191 & 3.8 \\
\hline Network size & $0.005^{\mathrm{b}}$ & 0.0012 & 3.97 \\
\hline Network intensity & $-0.0164^{b}$ & 0.0035 & -4.71 \\
\hline $\begin{array}{l}\text { Emotional support from self-employed } \\
\text { household members }\end{array}$ & -0.118 & 0.117 & -1.01 \\
\hline Loans from strong ties & $-0.015^{\mathrm{a}}$ & 0.0068 & -2.2 \\
\hline \multicolumn{4}{|l|}{ Additional control variables } \\
\hline $\begin{array}{l}\text { Number of household members } \\
\text { working in the enterprise }\end{array}$ & -0.0021 & 0.0439 & -0.05 \\
\hline Current age & $-0.0162^{a}$ & 0.0086 & -1.87 \\
\hline Female & $-0.534^{\mathrm{b}}$ & 0.173 & -3.09 \\
\hline Tenure & $-0.034^{\mathrm{a}}$ & 0.18 & -1.82 \\
\hline Firm labor size & $0.239^{b}$ & 0.079 & 3.01 \\
\hline Firm economic size & -0.0072 & 0.045 & 0.016 \\
\hline Firm age & -0.007 & 0.014 & -0.5 \\
\hline Capital intensive industry & $0.0574^{a}$ & 0.0264 & 2.17 \\
\hline Registered under Enterprise Law & $-0.472^{a}$ & 0.219 & -2.15 \\
\hline Intercept & 0.071 & 0.908 & 0.08 \\
\hline Wald $\chi^{2}(16)$ & & $260.45^{b}$ & \\
\hline Log likelihood & & -2468.8239 & \\
\hline Number of observations & & 6884 (1721 groups) & \\
\hline
\end{tabular}

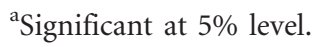

bignificant at $1 \%$ level.

Entrepreneurs having professional education are less likely to encounter capital constraints. Prior knowledge will help them actively to acquire financial resources from other income or loan sources. This is consistent with other comparable studies by Bosma et al. (2004) and Parker and van Praag (2006). However, the estimated 
coefficient is relatively much smaller in absolute terms even though it is statistically significant with a $P$-value of $4.4 \%$. Others kept constant, professional education from university, college, and technical high school relaxes the capital constraint by 0.24 percentage points.

Education level is one important indicator for borrowers' liquidity level, based on which lenders determine their loan grants. However, the economic effect of education is much lower than that found in other studies, which stems from the unique characteristics of the credit market in Vietnam, where the informal credit market (black market) is developed (Rand, 2007) and the formal credit market (social policy and commercial banks) mainly prioritizes disadvantaged entrepreneurs or entrepreneurs with political connections for loans. The banking sector in Vietnam is government controlled; thus, credit policies are mainly politics based and only market based in those credit-prioritized sectors. On the other hand, to obtain formal loans, entrepreneurs need to have adequate collateral (such as certificate of land ownership). Rand and Tarp (2007) claim that 30\% of entrepreneurs who do not apply for loan should be considered as credit constrained, as they do not have adequate collateral. Other human capital variables (industry and self-employment experience) are also statistically significant in explaining the likelihood of entrepreneurs' capital constraints. While self-employment experience helps entrepreneurs to relax their capital constraints, industry experience worsens the potential constraint. The results are consistent with Parker and van Praag (2006) although their results are not statistically significant. It is our conjecture that experience from previous business start-up equips entrepreneurs with the ability to overcome initial financial challenges, either being able to call for loans from both formal and informal sources or gaining financial support and investments from participating social business network. However, experience from working in the same industry will enable entrepreneurs to discover and recognize more entrepreneurial opportunities, which are available for profitable exploitation, and thus expose themselves to higher demands for investment capital.

Regarding the impact of social capital on entrepreneurs' financial capital constraint, network participation turns out to be positively related to capital constraint of the entrepreneur. Network members are significantly more capital constrained than nonmembers. It could be either that more constrained entrepreneurs join networks to seek for financial support (self-selection) or the causal effect could be the other way around: network members discover more business opportunities from joining the network, which requires them to call for more investment capital, and thus become capital constrained. It could also be the case that formal networks in Vietnam do not bring expected financial benefits to members, such as sharing resources and capital. In other words, we need to control for the endogeneity of capital constraint to investigate the real effects of formal networks in Vietnam. When we look at the effect of personal network structure (network size and network intensity) on the likelihood of capital constraints, it seems that the latter assumption may be 
more appropriate. Personal network membership does not help the entrepreneur to reduce his/her capital constraint from the size of the network, i.e. number of members within the network, but rather from the frequency of assistance from these contacts. In this respect, we have to recall that in Vietnam entrepreneurs might be involved in formal network activities for political reasons rather than businessrelated ones. This in turn may imply that network activities are limited to the facilitation of the policy-making process of the government. But before drawing any straightforward conclusion, it is worth looking at the results accruing from analysis of the effect of network participation on the performance of firms in our sample (see Section 5.2 below).

Other findings from control variables show that older and female entrepreneurs face less capital constraints than their younger and male counterparts. This suggests that older entrepreneurs might get more experience of how to obtain external capital from the credit market and that women are more able to obtain resources from their partners. As expected, leader's tenure has negative effect on his/her capital constraint. Longer tenure goes together with richer experience in overcoming any business operational challenges and stronger commitment to a smooth succession process by not engaging in risky and capital-intensive business adventures. We also find statistical support for our assumption that firms formally registered under the Enterprise Law are less capital constrained. Their formality enables them to have easier access to external capital sources under banks' screening system. Finally, larger firms, in terms of labor size, have more constraints for investment capital than smaller ones do.

\subsection{Second step: The effect of capital constraints on entrepreneurial performance}

We now present results from estimation of the structural equation, the second stage of the two-stage IV regression. The results, summarized in Table 7, are based on both panel random effect and IV estimators. In general, estimated coefficients from IV regression with business operating profit as the dependent variable are more significant (even reported with robust standard errors) and reasonable than those from the random regression and IV regression with growth of sales as the dependent. The Hausman specification test indicates that IV regression with profit as the dependent variable is preferable at $1 \%$ significance level compared with the IV regression with growth of sales as the dependent. ${ }^{12}$

In terms of the effect of capital constraints on entrepreneurs' business incomes, the interesting finding here is the positive coefficient of capital constraints (CAPCON) that shows a positive influence of capital constraints on entrepreneurial performance. In fact, it implies that other things constant, being capital constrained

\footnotetext{
${ }^{12} \mathrm{H}_{0}$ : difference in coefficients not systematic $\chi^{2}(23)=7737.3 ; P=0.0000$
} 


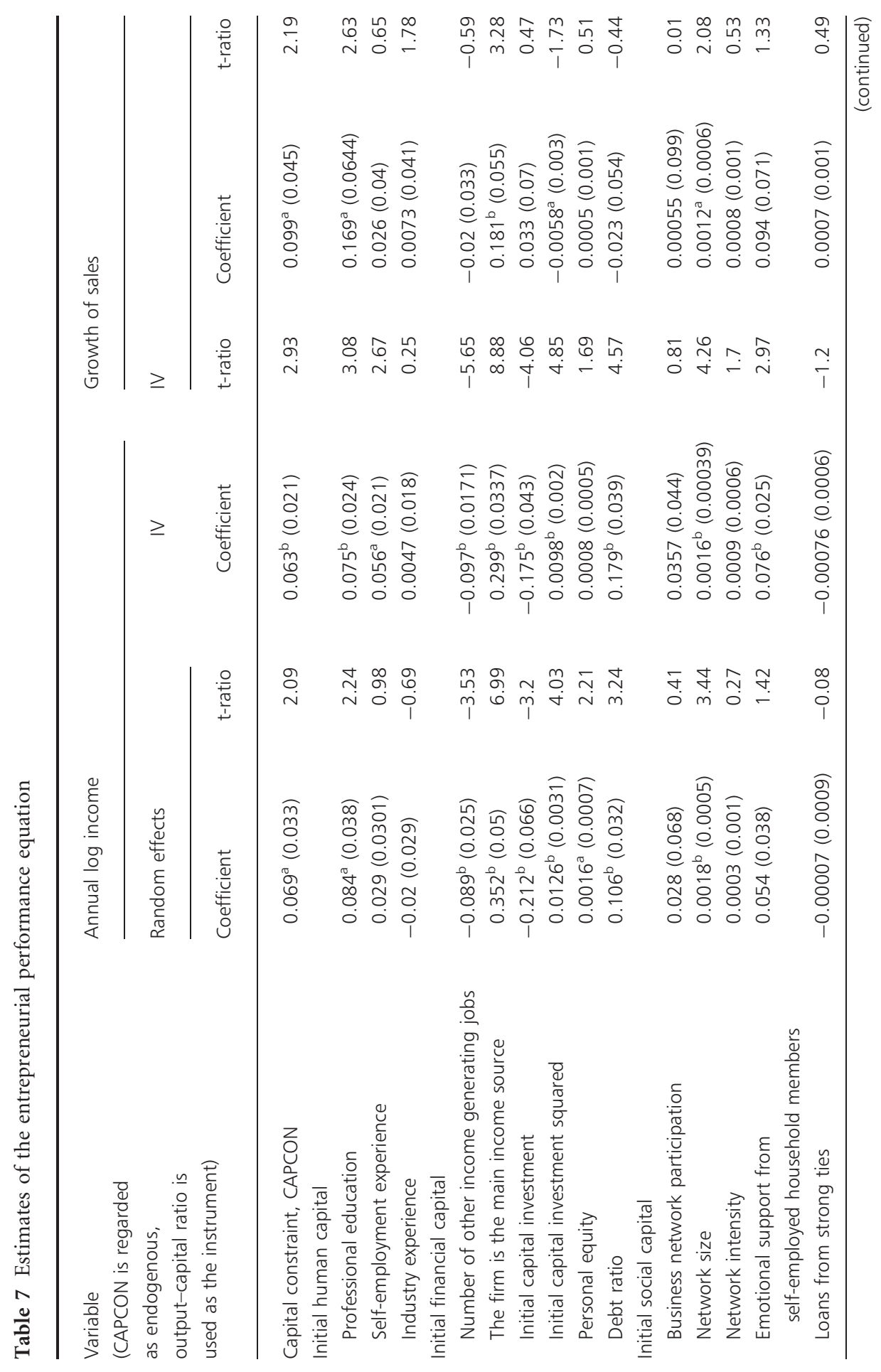

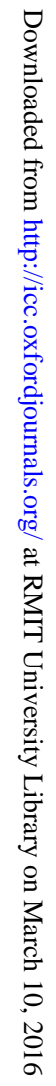




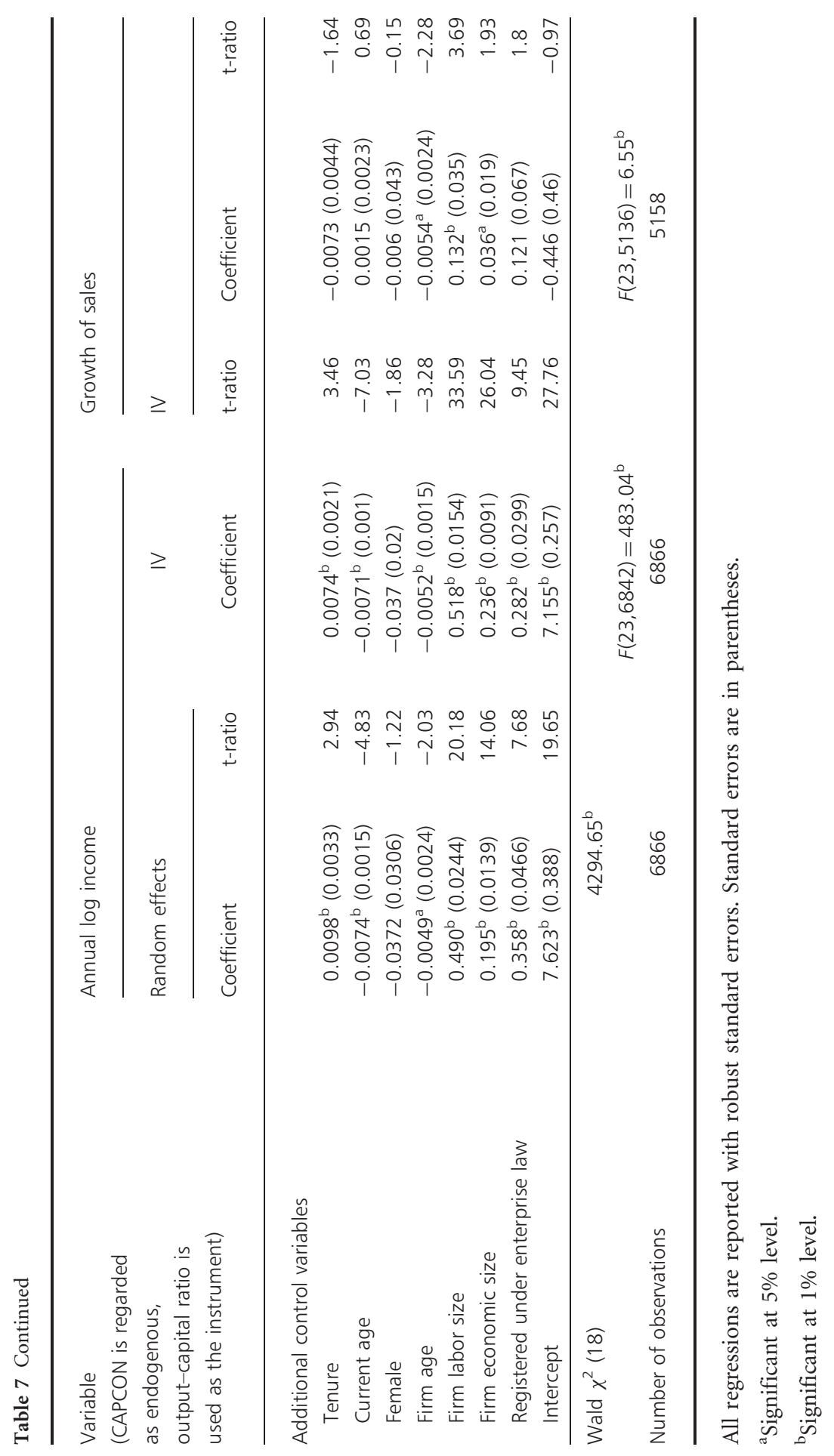


(as compared with not being) increases entrepreneurs' average business incomes by $6.3 \%$ and growth of sales by about $9 \%$. The size of this effect appears substantial, although it should be borne in mind that the average extent of capital constraints faced by entrepreneurs in our sample is $26 \%$ (450 entrepreneurs out of 1721). This result is consistent with those by Malesky and Taussig (2009), who found that political connections are an ineffective tool for channeling bank credit to the most profitable investors. In fact, these authors provide evidence that Vietnamese commercial banks place greater value on connections than performance, with the consequence that a large share of credit is allocated to enterprises in less competitive industries and regions. This leads to the fact that, paradoxically, firms with greater access to bank loans are no more profitable and sometimes even less profitable than firms without connections.

To explain the above finding, we propose three additional reasons.

First, the informal credit market in Vietnam is developed sufficiently to mitigate pressure from capital constraints. Capital-constrained firms can easily obtain informal loans from friends, relatives, or even black market. One possibility for those entrepreneurs who obtain loans from informal sources (mostly from friends and relatives) is that they can even perform better due to the absence of monthly interest pressure.

Second, when we compare the mean profit between the capital-constrained group and the nonconstrained group, it turns out that the constrained firms have much higher profit than the others. A $t$-test on an equal-variances assumption of profit means for the two groups is also included. Based on the evidences in Tables 8 and 9, we can reject the equal-variances assumption to support the one-tailed test that the profit mean of the nonconstrained group is smaller than that of the constrained group at 5\% significance level. Thus, capital-constrained firms in Vietnam (mostly young and new start-ups) are those firms in the "full bloom" of development. They are constrained because they need capital for newly recognized entrepreneurial opportunities. The credit obtained is used for new profitable investments, not for daily business operations. Nonconstrained firms do not apply for loans simply because they do not have any new investments that are in need of capital.

Third, the debt share of enterprises in our sample is low (around 10\% of total assets) confirming the results in Rand (2007) showing that external debt is not among the preferred financing strategies by Vietnamese (small) firms. It is also worth noting that even when enterprises obtain some credit, $60 \%$ of the "nonconstrained" group still has a need for loans.

The effect of education proxied by the likelihood of obtaining professional education is statistically greater than zero, which means that it plays an essential role in differentiating the performance of entrepreneurs. The magnitude of $\beta_{\text {education }}$ coefficient reflects the significant economic importance of educational level, obtaining professional education from university, college, and technical high school is likely to bring approximately $7.5 \%$ more profits and higher growth of sales by $12 \%$. The 
Table 8 Gross profit comparison between capital-constrained and nonconstrained firms (in 1000VND)

\begin{tabular}{|c|c|c|c|c|c|c|}
\hline Groups & Observation & Mean & SE & SD & \multicolumn{2}{|c|}{ 95\% Confidence interval } \\
\hline $\begin{array}{l}\text { Non capital-constrained } \\
\text { firms }\end{array}$ & 5108 & $109,342.8$ & 5924.668 & $423,437.6$ & $97,727.87$ & $120,957.6$ \\
\hline $\begin{array}{l}\text { Capital-constrained } \\
\text { firms }\end{array}$ & 1776 & 123,950 & 7155.011 & $301,530.9$ & \multirow[t]{2}{*}{$109,916.8$} & \multirow[t]{2}{*}{$137,983.1$} \\
\hline Analysis of variance: & & & & & & \\
\hline \multicolumn{7}{|c|}{ Ho: mean (nonconstrained $)-$ mean $($ constrained $)=$ diff $=0$} \\
\hline & \multirow{3}{*}{$\begin{array}{l}\text { Ha: } \operatorname{diff}<0 \\
t=-1.3404 \\
P<t=0.0901\end{array}$} & \multicolumn{2}{|c|}{$\mathrm{Ha}: \operatorname{diff} !=0 \quad \mathrm{Ha}$} & Ha: $\operatorname{diff}>0$ & & \\
\hline & & \multicolumn{2}{|c|}{$t=-1.3404$} & $=-1.3404$ & & \\
\hline & & \multicolumn{2}{|c|}{$P>|t|=0.1802$} & $P>t=0.9099$ & & \\
\hline
\end{tabular}

Note: diff! $=0$ : difference is not equal to zero, i.e. gross profit of capital-constrained firms is not statistically equal to gross profit of non capital-constrained ones.

Table 9 Growth of sales comparison between capital-constrained and nonconstrained firms

\begin{tabular}{|c|c|c|c|c|c|c|}
\hline Groups & Observation & Mean & SE & SD & \multicolumn{2}{|c|}{ 95\% Confidence interval } \\
\hline Non capital-constrained firms & 3862 & 0.31022 & 0.025 & 1.5537 & 0.2612 & 0.3592 \\
\hline Capital-constrained firms & 1296 & 0.3879 & 0.0376 & 1.3557 & 0.3141 & 0.4618 \\
\hline \multicolumn{7}{|l|}{ Analysis of variance: } \\
\hline \multicolumn{7}{|c|}{ Ho: mean(nonconstrained $)-$ mean $($ constrained $)=$ diff $=0$} \\
\hline \multicolumn{2}{|c|}{ Ha: $\operatorname{diff}<0$} & \multicolumn{2}{|c|}{ Ha: diff! $=0$} & \multicolumn{2}{|c|}{ Ha: diff $>0$} & \\
\hline \multicolumn{2}{|c|}{$\mathrm{t}=-1.6082$} & \multicolumn{2}{|c|}{$t=-1.6082$} & \multicolumn{2}{|c|}{$t=-1.6082$} & \\
\hline \multicolumn{2}{|c|}{$P<t=0.0539$} & \multicolumn{2}{|c|}{$P>|t|=0.1079$} & \multicolumn{3}{|c|}{$P>t=0.9461$} \\
\hline
\end{tabular}

Note: diff! $=0$ : difference is not equal to zero, i.e. gross profit of capital-constrained firms is not statistically equal to gross profit of non capital-constrained ones.

indirect effect of education through the capital constraint can be calculated by multiplying the estimated parameter of professional education in the reduced form with the estimated parameter of CAPCON in the structural equation, $\beta_{\mathrm{C}} \alpha_{\mathrm{E}}=-0.246 \times 0.063=-0.015$. This suggests a total rate of return from education for entrepreneurs of $6 \%\left(\beta_{\mathrm{C}} \alpha_{\mathrm{E}}+\beta_{\mathrm{E}}=0.075-0.015\right)$. One of the reasons why education significantly reduces the likelihood of capital constraints of entrepreneurs is related to its role of key screening criteria for offering credits, even if this explanation may be more appropriate for the screening process of commercial banks where they aim to maximize profits from their investment decisions. Loans from social policy 
banks are often granted to disadvantaged entrepreneurs or those under preferentialsupported policies.

However, given the fact that attaining professional education level from low or no education level requires at least 3 years (for instance, the shortest path is from secondary school to technical high school), i.e. approximately an average rate of return of maximum $2 \%$ per year, a comparison with other OLS estimates of return to education in entrepreneurship reveals that this estimate is somewhat lower than previous findings. For example, in a survey of 21 previous studies dealing with the relationship between education and entrepreneurial earnings, Van der Sluis et al. (2003) report an average rate of return of $6.1 \%$ for studies based on US data, with a somewhat lower average rate of return for European studies. Parker and van Praag (2006) find the rate of return to schooling of Dutch entrepreneurs to be $7.2 \%$. Trostel et al. (2002) pooling microsamples across 28 countries suggest a worldwide OLS estimate of the rate of return to schooling of $4.8 \%$ for men and $5.7 \%$ for women.

For a dynamic and transition economy as Vietnam's, market experience from operating the business in practice is more important in boosting entrepreneurial performance than the formal education achieved at schools, which is always under the controversial complaints that education does not meet labor market's demands. However, similar to capital constraint equation, we could only find the statistically significant positive effects of prior entrepreneurial experience (self-employment experience) on entrepreneurial gross income. Other things held constant, entrepreneurs having self-employment experience are likely to generate $5.6 \%$ profit more than inexperienced peers. While some of the information and skills necessary to exploit an opportunity can be learned through education or through managerial and industry experience, much of important information and knowledge about exploiting opportunities can only be learned by doing. Empirical studies generally support this positive relationship (Gimeno et al., 1997; Bosma et al., 2004; Santarelli and Tran, 2012). Industry experience also enables entrepreneurs to enhance their performance as well, but the effect is not significant.

Regarding initial financial capital, the fact that entrepreneurs have other incomegenerating jobs and do not consider the firm as their main source of income significantly erodes entrepreneurial motivation in boosting firm performance. We witness the positive leveraging effect of debt over the firm's capital structure through positive effect of the debt ratio: Firms may be more motivated and committed to perform productively and efficiently when they stay under the pressure of incurring costs of capital and paying back loans. We also witness the negative and increasing effect of capital required on firm income. Large size of initial capital investment required reflects high sunk cost of capital intensive industry, and thus placing higher risk for entrepreneurs to break even and generate sustainable income. Personal equity does not have statistically significant effects on entrepreneurial performance, but it helps to relax capital constraints. 
Consistent with the results from the capital constraint equation, social capital from weak ties (formal business association participation) does not enhance entrepreneurial performance significantly. Network members do not obtain the benefits of relaxing the constraints, as well as other intangible benefits to foster their income. Consistent with recent findings by Santarelli and Tran (2013) and De Jong et al. (2012), the reason for the scant significance of the coefficient of our social capital variable may be found in the fact that business networks in Vietnam are mainly politics-based, rather than economics-based. In the recent report on characteristics of the Vietnamese business environment from the follow-up survey in 2011, the majority of firms report that the most important reasons for joining business association are due to its provision of services concerning communication of new policies and laws to firms and other private sector services such as trade fairs, which are hard to be capitalized in real economic effects. Only 20 percent claim that network membership provides a preferential route for accessing credit from trading partners ${ }^{13}$ (Ciem, 2012). However, when we investigate the impacts of entrepreneurs' personal network structure, network size and network intensity-defined as the pattern of relationships that are engendered from the direct and indirect ties among actors (Hoang and Antoncic, 2003) — the coefficient of network size is statistically significant despite being numerically small. Because network size is positively related to the likelihood of being capital constrained of family firms (from the analysis of capital constraint equation above) and capital constrained firms outperform non-capital constrained ones (mentioned above), it is logical to interpret that those firms having more useful contacts in their network will discover more business opportunities from network information sharing, and thus are thirsty for more investment capital (being capital constrained), and on trying by all means to mobilize sufficient capital from different sources to exploit the opportunities, they produce positive growth and development for their firms. The insignificant effect of network frequency, on the other hand, indicates that the quality of network assistance is essentially more important than the quantity or frequency of network assistance. Regarding the effect of strong ties on business income, the benefit is limited to emotional support from selfemployed family members only. All these findings reconfirm the equivalent study by Santarelli and Tran (2013) on the effect of social capital on entrepreneurial performance of Vietnamese manufacturing private firms.

We also find interesting effects in relation to some of the other control variables in Table 7. Both younger entrepreneurs and younger firms perform better. The significant negative sign of the "age" parameters shows the negative relationship between entrepreneurs' age and their entrepreneurial profit gained. An entrepreneur with 10

\footnotetext{
${ }^{13}$ As shown by McMillan and Woodruff (1999), customers identified through business networks are likely to receive large amounts of commercial credit from their trading partners. Nevertheless, this does not necessarily imply that the recipients of this kind of external financing are firms characterized by superior economic performance (cf. Malesky and Taussig, 2009).
} 
years of seniority in the business is estimated to earn approximately $7.1 \%$ profit less. This result confirms findings by Cucculelli and Micucci (2008), Parker and van Praag (2006), and Miller (1991), who found a negative relationship between the two variables: that is, aging makes the contribution of the founder progressively less valuable for company performance. Age may be a salient predictor of entrepreneurial behaviors in family firms because their CEO is often preoccupied with succession issues as they age (Feltham et al., 2005). As succession grows nearer, the aging CEO may place greater importance on a smooth transition with fear of losing family wealth than on the need to pursue risky entrepreneurial ventures. In a dynamic business environment of a transitional economy as Vietnam's, the rules of games are continuously changing and the age-performance relationship is more responsive to aging. On the other hand, longer tenure of the leaders exerts considerably positive influence on firm performance. Tenure inspires entrepreneurial behavior because it allows the entrepreneur to accumulate a wealth of knowledge and experience, making him or her better able to select appropriate entrepreneurial behaviors, thereby increasing the subsequent entrepreneurial performance (Levesque and Minniti, 2006). Long CEO tenure may also allow the CEO to build valuable relationships among organizational networks. However, longer tenure has been found to be more likely to stimulate entrepreneurs to conform to industry norms and compromise the comfortable status quo. Zahra (2005) found that CEO tenure was negatively related to innovativeness in his study of more than 2000 family firms. Formally registered firms under the Enterprise Law are likely to perform more profitably than unregistered counterparts. Finally, younger firms and larger firms, in both labor size and economic size, get higher profit. There is no difference in terms of profitability between male and female entrepreneurs.

\section{Discussion and suggestions for policy actions}

The shift from centrally planned economy to market economy in Vietnam has led to the emergence of a large number of private enterprises, especially family firms. For these businesses to remain competitive in both local and international markets, it is important to understand various constraints that impede their survival and prosperity. This article is the first investigation that attempts to investigate the extent to which the performance of a family business venture, once started, is affected by capital constraints at the time of inception. We have taken into account the possibility that human and social capital might also have an indirect effect on firm performance by facilitating access to financial capital, thus diluting any capital constraint. We recognized the likely endogeneity of capital constraint, and thus used IV estimation. Our principal findings are fourfold.

First, other things held constant, entrepreneurs who suffer from capital constrains earn on average $4.9 \%$ more profit than those who do not. Although not intuitively 
understandable as most of the literature on capital constraints finds a negative effect of the constraint on entrepreneurial performance (see, e.g. Parker and van Praag, 2006), this finding is sizeable in economic terms, fully consistent with the resource dependency theory approach, and corroborated by the results of other studies conducted for Vietnam (e.g. Malesky and Taussig, 2009).

Second, the share of the entrepreneur's own capital is positively related to entrepreneurial performance, even though this relationship is not statistically strong.

Third, educational level significantly reduces the likelihood of entrepreneurs' facing capital constraints. This finding is consistent with the comparable studies (Bosma et al., 2004; Parker and van Praag, 2006), which claim that educational level relaxes the pressure from capital constraints.

Fourth, when we look at the structure and quality of entrepreneurs' personal networks, and correct for the effect of endogeneity of capital constraints on entrepreneurial performance, we find that entrepreneurs having more useful business contacts exhibit superior performance. However, the frequency of assistance does not have a significant effect on family firms' performance. The real benefits of social relationships for family firms seem to stem from the strength and quality of network contacts, rather than shallow and formal participation. The nature of business networks in Vietnam is still mainly political and somewhat compulsory for established incumbent firms in capital-intensive or mature industries. Nevertheless, as shown by McMillan and Woodruff (1999) for Vietnam and other authors for Russia (Batjargal, 2007), Eastern Europe (Paldam and Svendsen, 2000), and China (Koch, 2005), evidences of social capital benefits from business network participation are being observed also in transitional economies. Therefore, future policy action should encourage the establishment of genuinely business-oriented networks (rather than politically based) to support directly entrepreneurs, especially small-sized ones, in both their daily operations and long-term strategic management. This finding opens further space for future research on the diversity, concentration dynamic interaction between different types of social networks, and benefits obtained from them because a weakness of our study is that we have not been able to isolate various characteristics of networks (functions, diversity, strength of ties, density, degree of centrality, and so forth) owing to the limitation of data.

In terms of policy implications, when human capital and financial capital are interrelated and endogenous, many governments support the dual-track approach that involves attempting to soften capital constraints while simultaneously developing initiatives to deepen human capital (Parker and van Praag, 2006). However, this approach may be questionable for the case of Vietnam. This is due to the fact that capital constraints in Vietnam are not the negative signal to show the poor performance of firms, but the positive sign of fast growth instead. Thus, except for prioritized loans for disadvantaged entrepreneurs, credits for entrepreneurial investments, in general, are signal of economic development, if they are considered to be feasible and profitable. 
A potential weakness of this research lies in the fact that we only consider those firms surviving from the year of establishment until 2006 to investigate their continuous performance for 4 years in a balanced panel data. Thus, we are unable to track the capital constraints of bankrupting firms to explore whether it has influences on family firms' survival. In addition, the findings might be influenced by specific features of the Vietnamese cultural and institutional environment and therefore not be applicable to other transition economies.

\section{Acknowledgements}

The authors thank an anonymous reviewer for many helpful suggestions. A previous version of this article has been presented at the 2013 Babson College Entrepreneurship Research Conference (BCERC). Enrico Santarelli acknowledges financial support from University of Bologna (RFO2011).

\section{References}

Abrami, R. (2003), 'Entrepreneurship in Vietnam: transformation and dynamics,' Journal of Asian Studies, 62(2), 713-715.

Acs, Z. J. and D. B. Audretsch (1987), 'Innovation, market structure, and firm size,' Review of Economics and Statistics, 69(4), 567-574.

Aldrich, H. and C. Zimmer (1986), 'Entrepreneurship through social networks,' in D. L. Sexton and R. W. Smilor (eds), The Art and Science of Entrepreneurship. Ballinger: Cambridge, MA.

Amit, R., L. Glosten and E. Muller (1990), 'Entrepreneurial ability, venture investments, and risk sharing,' Management Science, 36(10), 1232-1245.

Amit, R., J. Brander and C. Zott (1998), 'Why do venture capital firms exist? Theory and Canadian evidence,' Journal of Business Venturing, 13(6), 441-466.

Astrachan, J. H. and M. C. Shanker (2003), 'Family businesses' contribution to the U. S. economy: a closer look,' Family Business Review, 16(3), 211-220.

Astrachan, J. H. (2010), 'Strategy in family business: towards a multidimensional research agenda,' Journal of Family Business Strategy, 1(1), 6-14.

Audretsch, D. B. (1995), Innovation and Industry Evolution. MIT Press: Cambridge, MA.

AusAid (2000), Vietnam land administration. Working Paper 4. The Australian Government's Overseas Aid Program, http://www.ausaid.gov.au/publications/Documents/vietnam_wp4. pdf.

Barslund, M. and F. Tarp (2008), 'Formal and informal rural credit I four provinces of Vietnam,' Journal of Development Studies, 44(4), 485-503.

Batjargal, B. (2007), 'Comparative social capital: networks of entrepreneurs and venture capitalists in China and Russia,' Management and Organization Review, 3(3), 397-419. 
Baum, C. F. and M. E. Schaffer (2003), 'Instrumental variables and GMM: estimation and testing,' Stata Journal, 3(1), 1-31.

Bosma, N. S., C. M. van Praag and G. de Wit (2000), 'Determinants of successful entrepreneurship,' Research Report 0002/E. EIM: Zoetermeer.

Bosma, N. S., C. M. van Praag, A. R. Thurik and G. de Wit (2004), 'The value of human and social capital investments for the business performance of startups,' Small Business Economics, 23(3), 227-236.

Breusch, T., M. Ward, H. Nguyen and T. Kompas (2011), 'On the fixed-effects vector decomposition,' Political Analysis, 19(2), 123-134.

Brown, B. and J. E. Butler (1995), 'Competitors as allies: a study of entrepreneurial networks in the U.S. wine industry,' Journal of Small Business Management, 3(1), 57-66.

Browning, M. and A. Lusardi (1996), 'Household saving: micro theories and micro facts,' Journal of Economic Literature, 34(4), 1797-1855.

Bruderl, J. and P. Preisendorfer (1998), 'Network support and the success of newly founded businesses,' Small Business Economics, 10(3), 213-225.

Burkart, M., F. Panunzi and A. Shleifer (2003), 'Family firms,' Journal of Finance, 58(5), 2167-2201.

Carney, M. (2005), 'Corporate governance and competitive advantage in family-controlled firms,' Entrepreneurship Theory and Practice, 29(3), 249-265.

Chrisman, J. J., J. H. Chua and R. A. Litz (2004), 'Comparing the agency costs of family and non-family firms: conceptual issues and exploratory evidence,' Entrepreneurship Theory and Practice, 28(4), 335-354.

Chrisman, J. J., J. H. Chua and P. Shama (2005), 'Trends and directions in the development of a strategic management theory of the family firm,' Entrepreneurship Theory and Practice, 29(5), 555-575.

Ciem (2012), Characteristics of the Vietnamese Business Environment: Evidence from a SME Survey in 2011. Labor-Social Publishing House: Vietnam, Nhà xuất bản Lao động - Xã hội (Labor-Social Publishing house).

Claessens, S., S. Djankov, J. Fan and L. Lang (2002), 'Disentangling the incentive and entrenchment effects of large stockholdings,' Journal of Finance, 57(6), 2741-2770.

Coleman, J. S. (1988), 'Social capital in the creation of human capital,' American Journal of Sociology, 94(Suppl.), S95-S120.

Cooper, A. C., F. J. Gimeno-Gascon and C. Y. Woo (1994), 'Initial human and financial capital as predictors of new venture performance,' Journal of Business Venturing, 9(5), 371-395.

Cucculelli, M. and G. Micucci (2008), 'Family succession and firm performance: evidence from italian family firms,' Journal of Corporate Finance, 14(1), 17-31.

Davidsson, P. and B. Honig (2003), 'The role of social and human capital among nascent entrepreneurs,' Journal of Business Venturing, 18(3), 301-331. 
De Jong, G., P. A. Tu and H. van Ees (2012), 'Which entrepreneurs bribe and what do they get from It? Exploratory evidence from Vietnam,' Entrepreneurship Theory and Practice, 39(2), 323.

Deaton, A. (1990), 'Price elasticities from survey data: extension and Indonesian results,' Journal of Econometrics, 44(3), 281-309.

Deeds, D., D. DeCarolis and J. E. Coombs (1998), 'Firm-specific resources and wealth creation in high technology ventures: evidence from newly public biotechnology firms,' Journal of Business Venturing, 12(1), 31-46.

Dilek, C., V. K. Gupta and E. E. Karadeniz (2012), 'What the numbers tell: the impact of human, family and financial capital on women and men's entry into entrepreneurship in Turkey,' Entrepreneurship and Regional Development, 24(1-2), 29-51.

Dinh, Q. H., T. B. Dufhues and G. Buchenrieder (2012), 'Do connections matter? Individual social capital and credit constraints in Vietnam,' European Journal of Development Research, 24(3), 337-358.

Dufhues, T., G. Buchenrieder and H. D. Quoc (2012), 'Social capital and loan repayment performance in Northern Vietnam,' Agricultural Economics, 43(3), 277-292.

Dyer, W. G. and W. Handler (1994), 'Entrepreneurship and family business: exploring the connections,' Entrepreneurship Theory and Practice, 19(1), 71-84.

Dyer, W. G. (1992), The Entrepreneurial Experience: Confronting Career Dilemmas of the Startup Executive. Jossey-Bass: San Francisco, CA.

Dyer, W. G. (2006), 'Examining the "family effect" on firm performance,' Family Business Review, 19(4), 253-273.

Evans, D. and B. Jovanovic (1989), 'An estimated model of entrepreneurial choice under liquidity constraints,' Journal of Political Economy, 97(4), 808-827.

Faccio, M., L. H. R. Lang and L. Young (2001), 'Dividends and expropriation,' American Economic Review, 91(1), 54-78.

Fama, E. and M. C. Jensen (1983), 'Separation of ownership and control,' Journal of Law and Economics, 26(2), 301-325.

Fazzari, S. M., R. G. Hubbard and B. C. Petersen (1988), 'Financing constraints and corporate investment,' Brookings Papers on Economic Activity, 115, 695-713.

Feder, G., L. J. Lau, J. Y. Lin and X. Luo (1990), 'The relationship between credit and productivity in Chinese agriculture: a micro-economic model of disequilibria,' American Journal of Agricultural Economics, 72(5), 1151-1157.

Feltham, T. S., F. Feltham and J. J. Barnett (2005), 'The dependence of family businesses on a single decision-maker,' Journal of Small Business Management, 43(1), 1-15.

General Statistics Office of Vietnam (GSO) (2007), Statistic Yearbook 2007. Statistical Publisher: Hanoi.

General Statistics Office of Vietnam (GSO) (2010), Statistic Yearbook 2010. Statistical Publisher: Hanoi. 
Gersick, K. E., J. A. Davis, M. M. Hampton and I. Lansberg (1997), Generation to Generation: Life Cycles of the Family Business. Harvard Business School Press: Cambridge, MA.

Gimeno, J., T. B. Folta, A. C. Cooper and C. Y. Woo (1997), 'Survival of the fittest? Entrepreneurial human capital and the persistence of underperforming firms,' Administrative Science Quarterly, 42(4), 750-783.

Glaeser, E. L., D. I. Laibson, J. A. Scheinkman and C. L. Soutter (2000), 'Measuring trust,' Quarterly Journal of Economics, 115(3), 811-846.

Glewwe, P. and H.-A. H. Dang (2011), 'Was Vietnam's economic growth in the 1990s propoor? An analysis of panel data from Vietnam,' Economic Development and Cultural Change, 59(3), 583-608.

Granovetter, M. (1973), 'The strength of weak ties,' American Journal of Sociology, 78(6), 1360-1380.

Greve, A. and J. W. Salaff (2003), 'Social networks and entrepreneurship,' Entrepreneurship Theory and Practice, 28(1), 1-22.

Gutterman, A. S. (2011), 'Entrepreneurship in Vietnam,' in A. S. Gutterman (ed.), Organizational Management and Administration: A Guide for Managers and Professionals. Thomson Reuters/West: New York, NY.

Hall, G., P. Hutchinson and N. Michaelas (2000), 'Industry effects on the determinants of unquoted SMEs' capital structure,' International Journal of the Economics of Business, 7(3), 297-312.

Hausman, J. (1978), 'Specification tests in econometrics,' Econometrica, 46(6), 1251-1271.

Hiemstra, A. M. F., K. G. van der Kooy and M. Frese (2006), 'Entrepreneurship in the street food sector of Vietnam - assessment of psychological success and failure factors,' Journal of Small Business Management, 44(3), 474-481.

Hitt, M. A., R. Duane Ireland, D. G. Sirmon and C. H. Trams (2011), 'Strategic entrepreneurship: creating value for individuals, organizations, and society, Academy of Management Perspectives, 25(2), 7-76.

Hoang, H. and B. Antoncic (2003), 'Network-based research in entrepreneurship: a critical review,' Journal of Business Venturing, 18(2), 165-187.

Hoang, V. and T. Dung (2009), 'The cultural dimensions of the Vietnamese private entrepreneurship,' The IUP Journal of Entrepreneurship and Development, 6(3-4), 54-78.

Jappelli, T. (1990), 'Who is credit constrained in the U.S. economy?' Quarterly Journal of Economics, 105(1), 219-234.

Johannisson, B. (1988), 'Business formation - a network approach,' Scandinavian Journal of Management, 4(3-4), 83-99.

Koch, B. J. (2005), 'Social capital in China: an experimental approach,' Paper presented at the annual meeting of the American Sociological Association, http://www.allacademic.com/meta/ p20678_index.html, retrieved August 21, 2008.

La Porta, R., F. Lopez-de-Silanes and A. Shleifer (1999), 'Corporate ownership around the world,' Journal of Finance, 54(2), 471-517. 
Levesque, M. and M. Minniti (2006), 'The effect of aging on entrepreneurial behavior,' Journal of Business Venturing, 21(2), 177-194.

Lin, N. (1990), 'Social resources and social mobility: a structural theory of status attainment,' in R. L. Breiger (ed.), Social Mobility and Social Structure. Cambridge University Press: New York, NY, pp. 247-271.

Lumpkin, G. T., L. Steier and M. Wright (2011), 'Strategic entrepreneurship in family business,' Strategic Entrepreneurship Journal, 5(4), 285-306.

Luo, X., L. Zhou and S. Liu (2005), 'Entrepreneurial firms in the context of China's transition economy: an integrative framework and empirical examination,' Journal of Business Research, 58(3), 277-284.

Malesky, E. J. and M. Taussig (2009), 'Where is credit due? Legal institutions, connections, and the efficiency of bank lending in Vietnam,' Journal of Law, Economics and Organization, 25(2), 535-578.

McCullagh, P. and J. A. Nelder (1989), Generalized Linear Models, 2nd edn. Chapman and Hall: New York, NY.

McMillan, J. and C. Woodruff (1999), 'Interfirm relationships and informal credit in Vietnam,' Quarterly Journal of Economics, 114(4), 1285-1320.

Miller, D. (1991), 'Generalists and specialists: two business strategies and their contexts,' in P. Shrivastava, A. Huff and J. Dutton (eds), Advances in Strategic Management. JAI Press: Greenwich, CT, pp. 3-41.

Miller, D., I. Le Breton-Miller and B. Scholnick (2008), 'Stewardship vs. stagnation: an empirical comparison of small family and non-family businesses,' Journal of Management Studies, 45(1), 51-78.

Miller, D., J. Lee, S. Chang and I. Le Breton-Miller (2009), 'Filling the institutional void: the social behavior and performance of family vs non-family technology firms in emerging markets,' Journal of International Business Studies, 40(5), 802-817.

Myers, S. (1984), 'The capital structure puzzle,' Journal of Finance, 39(3), 575-592.

Paldam, M. and G. T. Svendsen (2000), 'Missing social capital and the transition in eastern Europe,' Journal for Institutional Innovation, Development and Transition, 5(1), 21-34.

Parker, S. C. and C. M. van Praag (2006), 'Schooling, capital constraints, and entrepreneurial performance: the endogenous triangle,' Journal of Business and Economic Statistics, 24(4), 416-431.

Pennings, J. M., K. Lee and A. Van Witteloostuijn (1998), 'Human capital, social capital, and firm dissolution,' Academy of Management Journal, 41(4), 425-440.

Perman, S. (2006), 'Taking the pulse of family businesses,' Business Week, February 13.

Phuong, H. N. (2003), 'Entrepreneurship in Vietnam: just on the starting point of the race,' Proceedings of Entrepreneurship in Asia: Playbook for Prosperity. Maureen and Mike Mansfield Foundation Program, pp. 1-16. 
Plumper, T. and V. Troeger (2007), 'Efficient estimation of time-invariant and rarely changing variables in finite sample panel analyses with unit fixed effects,' Political Analysis, 15(2), $124-139$.

Poza, E. J., S. Hanlon and R. Kishida (2004), 'Does the family business interaction factor represent e resource or a cost?' Family Business Review, 17(2), 99-118.

Putnam, R. (1993), Making Democracy Work: Civic Traditions in Modern Italy. Princeton University Press: Princeton.

Rand, J. (2007), 'Credit constraints and determinants of the cost of capital in Vietnamese manufacturing,' Small Business Economics, 29(1-2), 1-13.

Rand, J. and F. Tarp (2007), Characteristics of the Vietnamese Business Environment: Evidence from a SME Survey in 2005. A Study Prepared under Component 5 - Business Sector Research of the Danida Funded Business Sector Programme Support. Vietnam Central Institute for Economic Management.

Rand, J. and F. Tarp (2012), 'Firm-level corruption in Vietnam,' Economic Development and Cultural Change, 60(3), 571-595.

Sahlman, W. A. (1990), 'The structure and governance of venture-capital organizations,' Journal of Financial Economics, 27(2), 473-521.

Santarelli, E. and R. Piergiovanni (1995), 'The determinants of firm start-up and entry in Italian producer services,' Small Business Economics, 7(3), 221-230.

Santarelli, E. and H. T. Tran (2012), 'Growth of incumbent firms and entrepreneurship in Vietnam,' Growth and Change, 43(4), 638-666.

Santarelli, E. and H. T. Tran (2013), 'The interplay of human and social capital in shaping entrepreneurial performance: the case of Vietnam,' Small Business Economics, 40(2), $435-458$.

Santarelli, E. and M. Vivarelli (2007), 'Entrepreneurship and the process of firms' entry, survival and growth,' Industrial and Corporate Change, 16(3), 455-488.

Sapienza, H. J. and A. K. Gupta (1994), 'Impact of agency risks and task uncertainty on venture capitalist CEO interaction,' Academy of Management Journal, 37(6), 1618-1632.

Schiller, B. R. and P. E. Crewson (2007), 'Entrepreneurial origins: a longitudinal inquiry,' Economic Inquiry, 35(3), 523-531.

Schulze, W. S., M. H. Lubatkin, R. N. Dino and A. Buchholtz (2001), 'Agency relationships in family firms: theory and evidence,' Organization Science, 12(2), 99-116.

Schumpeter, J. A. (1934), The Theory of Economic Development. Harvard University Press: Cambridge, MA.

Shane, S. and S. Venkataraman (2000), 'The promise of entrepreneurship as a field of research,' Academy of Management Review, 25(1), 217-226.

Shane, S. (2000), 'Prior knowledge and the discovery of entrepreneurial opportunities,' Organization Science, 11(4), 448-469. 
Sharma, P., J. J. Chrisman and J. H. Chua (2003), 'Succession planning as planned behavior: some empirical results,' Family Business Review, 16(1), 1-15.

Shim, J. and H. Okamuro (2011), 'Does ownership matter in mergers? A comparative study of the causes and consequences of mergers by family and non-family firms,' Journal of Banking and Finance, 35(1), 193-203.

Simon, D. G. and M. A. Hitt (2003), 'Managing resources: linking unique resources, management, and wealth creation in family firms,' Entrepreneurship Theory and Practice, 27(4), 339-358.

Smeltzer, L. R., B. L. Van Hook and R.W. Hutt (1991), 'Analysis and use of advisors as information sources in venture startups,' Journal of Small Business Management, 29(1), $10-20$.

Stewart, A. and M. A. Hitt (2012), 'Why can't a family business be more like a nonfamily business? Modes of professionalization in family firms,' Family Business Review, 25(1), $58-86$.

Stiglitz, J. E. and A. Weiss (1981), 'Credit rationing in markets with imperfect information,' American Economic Review, 71(3), 393-410.

Timmons, J. A. (1994), New Venture Creation, 4th edn. Irwin: Burr Ridge, IL.

Tran-Nam, B., D. Ch and Pham (eds) (2003), The Vietnamese Economy: Awakening the Dormant Dragon. RoutledgeCurzon: London.

Trostel, P., I. Walker and P. Woolley (2002), 'Estimates of the economic return to schooling for 28 countries, Labor Economics, 9(1), 1-16.

Unger, J. M., A. Rauch, M. Frese and N. Rosenbusch (2011), 'Human capital and entrepreneurial success: a meta-analytical review,' Journal of Business Venturing, 26(3), 341-358.

Van der Sluis, J., C. M. Van Praag and W. Vijverberg (2003), 'Entrepreneurship selection and performance: a meta-analysis of the impact of education in industrialized countries,' The World Bank Economic Review, 19(2), 225-261.

Venkataraman, S. (1997), 'The distinctive domain of entrepreneurship research: an editor's perspective,' Advances in Entrepreneurship, Firm Emergence, and Growth, Vol. 3, JAI Press: Greenwich, CT, pp. 119-138.

Verbeke, A. and L. Kano (2012), 'The transaction cost economics theory of the family firm: family-based human asset specificity and the bifurcation bias,' Entrepreneurship Theory and Practice, 36(6), 1183-1205.

Ward, J. L. (1988), 'The special role of strategic planning for family businesses,' Family Business Review, 1(2), 105-118.

Westhead, P. and C. Howarth (2006), 'Ownership and management issues associated with family performance and company objectives,' Family Business Review, 19(4), 301-16.

Wooldridge, J. M. (2000), Introductory Econometrics: A Modern Approach. South-Western: Cincinnati, $\mathrm{OH}$. 
World Bank (1999), Knowledge for Development. World Development Report. Oxford University Press: New York, NY.

World Bank (2005), A Better Investment Climate for Everyone. World Development Report. Oxford University Press: New York, NY.

Yordanova, D. I. (2011), 'Entrepreneurial orientation in family and non-family firms: evidence from Bulgaria,' International Journal of Economic Sciences and Applied Research, 4(1), 185-203.

Zahra, S. A. (2005), 'Entrepreneurial risk taking in family firms,' Family Business Review, 18(1), 23-40.

Zahra, S. A., J. C. Hayton, D. O. Neubaum, C. Dibrell and J. Craig (2008), 'Culture of family commitment and strategic flexibility: the moderating effect of stewardship,' Entrepreneurship Theory and Practice, 32(6), 1035-1054.

Zimmer, C. and H. Aldrich (1987), 'Resource mobilization through ethnic networks: kinship and friendship ties of shopkeepers in England,' Sociological Perspectives, 30(4), 422-445. 